\title{
BIO-ECONOMIC OPTIMAL LEVELS OF THE BALI STRAIT SARDINE FISHERY OPERATING IN A FLUCTUATING ENVIRONMENT
}

\author{
Purwanto \\ Researcher at Research Center for Fisheries Management and Conservation, Ancol-Jakarta \\ Received September 6-2010; Received in revised form January 28-2011; Accepted February 7-2011
}

\begin{abstract}
There was an indication that fishing intensity was not the only factor affecting the abundance of Bali sardine stock, as indicated by catch per unit effort, the high fluctuations in abundance of the fish stock may also be affected by environmental conditions. Therefore, this study formulated a bioeconomic model accommodating fishing effort and environmental variations for the Bali strait sardine fishery, and its application to estimate catch and resource rent is demonstrated and presented here. The result of analysis by using this model shows significant effects on the catch per unit effort of changes in the number of vessels and the climatic variation, which in turn, affects fishers' income, and resource rent. The result of the analysis also shows that the optimal levels of fishing effort required to catch the Bali strait sardine stock at the maximum sustainable yield and to generate optimal resource rent varied with southern oscillation. Meanwhile, the total allowable fishing effort for the Bali strait pelagic fishery targeting sardine stock agreed by both the Provincial Governances in year 1986 was in a single value, estimated with no consideration in the impact of climatic variation, and higher than that optimal level. Therefore, the total allowable fishing effort should be adjusted periodically on the basis of, at least, the climatic condition in order to achieve the economically optimal level of yield and rent.
\end{abstract}

KEYWORDS: $\quad$ resource rent, bio-economic, sardine fishery, climate change, Bali Strait

\section{INTRODUCTION}

Small pelagic fishery in the Bali Strait is unique. It is conducted by small scale fishery targeting a single species fish stock, i.e. the Bali sardine (Sardinella lemuru Bleeker, 1853) stock, in the relatively narrow waters situated in between Java and Bali Islands, to support processing industries located in the coastal area bordering the strait. This is one of the main area of fish processing industries in Indonesia. This fishery also supplies fish for consumption, supports marketing, and provides jobs.

The small pelagic resources in the Bali Strait have a long history of exploitation, using various traditional fishing gears. However, the fishery developed rapidly only after the introduction of purse seines during the early 1970 s, prompted by strong demand for fish as raw materials in processing industries. This fishing gear has become the main fishing gear used in the Bali Strait small pelagic fishery. Contribution of the purse seine fleet was about $93 \%$ of the total catch of Bali strait fishery (Merta et al., 2000). To meet the demand for fish, the number of purse seine vessels had increased considerably which in turn increased fishing pressure to fishery resources. In the early development of the Bali Strait fishery, increasing fishing vessels resulted in higher catches, resulting in greater quantity of raw material for processing industry, which led the industry to expand their processing capacity.
An uncontrolled increase in the number of purse seine vessels has led to the over exploitation of the sardine stock in the Bali Strait. The result of studies conducted by Sujastani \& Nurhakim (1982); Salim (1986); Merta (1992); Merta \& Eidman (1995) confirmed such situation. Sujastani \& Nurhakim (1982); Salim (1986) by using a surplus production model estimated that the biologically optimum fishing effort for the Bali sardine fishery were 190 and 207 units of purse seiners, respectively, and concluded that the sardine stock in the Bali Strait has been over exploited. The actual fishing efforts in year 1982 and 1986, for comparison, were 278 and 273 units, respectively. Ritterbush (1975); Merta (1992); Merta \& Eidman (1995) from stock assessment studies using analytical models have also concluded that the sardine stock in the Bali Strait has been over exploited. Over exploitation not only diminishes and threatens the sustainability of sardine stock but also dissipates resource rent, as reported by Purwanto (1992) from a bio-economic study on sardine fishery in that area.

However, there was an indication that fishing intensity was not the only factor affecting the abundance of Bali sardine stock, the catch, and the catch per unit effort in Bali sardine fishery have largely fluctuated even though relatively small changes in the number of vessels (Anonymous, 1999). The catch per unit effort indicates vessel productivity and fish stock 
abundance (Cadima, 2003). The high fluctuations in abundance of the fish stock may also be affected by environmental conditions. Consequently, the result of analysis using the traditional production model, which considers fishing effort variation only, would be bias. Furthermore, resource rent estimated on the basis of such model would also be misleading. Therefore, environmental phenomena should also be taken into account in the analysis (Freon, 1986). An attempt to include environmental parameters in the assessment of the Bali Strait sardine fishery has been made by Ghofar et al. (2000) by incorporating the southern oscillation index into the production model. The use of such modified production model in the analysis resulted in a better fit. Results of those studies suggest that the fishery is fully exploited during El Niño years, and over exploited during Anti El Niño years. In the analysis, however, Ghofar et al. (2000) did not directly modify the parameters of the production model. Unfortunately, no bio-economic study has been conducted to evaluate the impact of environmental conditions on the resource rent generation in the Bali Strait sardine fishery.

In this article, a bio-economic model accommodating fishing effort, and environmental variations is formulated for the Bali Strait sardine fishery and its application to estimate optimal catch and resource rent is demonstrated. The result of this analysis then is used to evaluate management policy.

\section{MATERIALS AND METHODS}

The bio-economic model used in this study, as also described by Clark (1976), is developed on the basis of the Schaefer (1957) production model. Basic equations of the bio-economic model are as follows:

$$
\begin{aligned}
& P(x)=T R(x)-T C(x) \text { (Resource Rent Function) .. (1 } \\
& \mathrm{TR}(\mathrm{x})=\mathrm{p} . \mathrm{G}(\mathrm{x}) \text { (Total Revenue Function) ........ (2 } \\
& \mathrm{TC}(\mathrm{x})=\mathrm{c} \cdot[\mathrm{r} / \mathrm{q}-(\mathrm{r} / \mathrm{q} \cdot \mathrm{K}) \cdot \mathrm{x}](\text { Total Cost Function) ... (3 } \\
& G(x)=r . x \cdot(1-x / K) \text { (Natural Population Growth } \\
& \text { Function) ..................................... (4 } \\
& \mathrm{x}=\mathrm{K}-(\mathrm{q} \cdot \mathrm{K} / \mathrm{r}) \cdot \mathrm{E} \text { (Biomass Function) ............. (5 } \\
& h=(q \cdot K) \cdot E-\left(q^{2} \cdot K / r\right) \cdot E^{2} \text { (Production Function) .... (6 }
\end{aligned}
$$

where:

$$
\begin{aligned}
& \mathrm{x}=\text { the stock biomass } \\
& \mathrm{p}=\text { price of fish } \\
& \mathrm{c}=\text { cost of fishing per unit effort }
\end{aligned}
$$

$r=$ the natural growth rate of population

$q=$ catchability coefficient

$\mathrm{K}=$ the environmentally limited maximum biomass or carrying capacity

$E=$ fishing effort

$\mathrm{h}=$ yield or total catch

The environmental conditions may affect the yield on parameters K, r, and/or q (Freon, 1986). Considering the data available, the biological submodel of the bioeconomic model are modified to take into account the effects of environmental variations by modifying the $\mathrm{K}$ and the r parameters. Southern oscillation index is used as a proxy for environmental conditions. The $r$ parameter is modified as follows:

$$
\mathrm{r}_{\mathrm{t}}=\mathrm{a}_{0}-\mathrm{a}_{1} \cdot \mathrm{S}_{\mathrm{t}}
$$

where:

$$
\begin{aligned}
& r_{t}=r \text { in year } t \\
& S_{t}=\text { southern oscillation index in year } t
\end{aligned}
$$

A method of analysis developed by Schnute (1977) was used to estimate parameters of the model:

$$
\begin{aligned}
& \operatorname{Ln}\left(U_{t+1} / U_{t}\right)=\left(a_{0}-a_{1} \cdot S_{t+1}\right)-b \cdot\left(U_{t}+U_{t+1}\right) / 2-q \cdot\left(E_{t}+E_{t+1}\right) / 2 \text {. (8 } \\
& K_{t}=\left(a_{0}-a_{1} \cdot S_{t}\right) /(q b)
\end{aligned}
$$

where:

$$
\begin{array}{ll}
\mathrm{a}_{0}, \mathrm{a}_{1}, \mathrm{~b}, \text { and } \mathrm{q}= & \text { coefficients } \\
\mathrm{S}_{\mathrm{t}+1} & \text { southern oscillation index in } \\
& \text { year } \mathrm{t}+1 \\
\mathrm{U}_{\mathrm{t}} \text { and } \mathrm{U}_{\mathrm{t+1}} & =\text { catch per unit effort in year } \mathrm{t} \\
& \text { and } t+1, \text { respectively } \\
\mathrm{E}_{t} \text { and } \mathrm{E}_{\mathrm{t}+1} & =\begin{array}{l}
\text { effort in year } t \text { and } t+1, \\
\text { respectively }
\end{array} \\
\mathrm{K}_{\mathrm{t}} & =\mathrm{K} \text { in year } \mathrm{t}
\end{array}
$$

The coefficients of equation (8) were estimated by ordinary least square. The modification of the bioeconomic model is undertaken by incorporating equations (7) and (9) into equations (1)-(6). The result of the modification can be categorised into biological and economic submodels, as presented in Appendix 1 and 2. The value of coefficients resulting from the statistical analysis then was used in the application of the bio-economic model.

The estimation of the coefficients of equation (8) used the catch and effort data from Merta et al. (2000); Yosidawati (2004), and the southern oscillation index from the Australian Bureau of Meteorology (2008) (Appendix 3). Adjustment of the catch data was undertaken before analysis in order to take into account under reported catch, which was estimated 
on the basis of various information to be about $60 \%$. Meanwhile, the development of equations (2) and (3) was conducted by using the data on cost of fishing and the price of sardines resulting from a field study in 2005 (Appendix 4).

\section{RESULTS AND DISCUSSION}

\section{Results}

\section{Resource Exploitation}

The following equation is the result of the statistical analysis:

$$
\begin{aligned}
\operatorname{Ln}\left(\mathrm{U}_{\mathrm{t}+1} / \mathrm{U}_{\mathrm{t}}\right)= & \left(4.35859-0.08982 \mathrm{~S}_{\mathrm{t+1}}\right) \\
& (4.077)^{\star *}(-5.889)^{\star *} \\
& -0.00625\left(\mathrm{U}_{\mathrm{t}}+\mathrm{U}_{\mathrm{t}+1}\right) / \\
& (-4.249)^{\star *} \\
& 2-0.01295\left(\mathrm{E}_{\mathrm{t}}+\mathrm{E}_{\mathrm{t}+1}\right) / 2 \ldots \\
& (-3.615)^{* *}
\end{aligned}
$$

$\mathrm{R}^{2}=0.78 ; \mathrm{n}=14 ;{ }^{* *}$ t-statistics in the parentheses are significant at $\mathrm{P}<0.005$.

On the basis of equations (8) and (10), the catchability coefficient was 0.01295 . Meanwhile, the natural growth rate and the carrying capacity were represented by the following equations:

$$
\begin{aligned}
& r_{t}=4.35859-0.08982 S_{t} \\
& K_{t}=53,881-1,110.4 S_{t}
\end{aligned}
$$

Based on equations (11) and (12), the natural growth rate and the carrying capacity were greater during El Niño episodes, as indicated by sustained negative values of the southern oscillation index. Consequently, the natural logistic growth rate was also greater (equation (13)). The natural logistic growth rate function of the sardine stock in the Bali Strait accommodating climatic variable was formulated on the basis of equations (4), (11), and (12) as follows:

$$
G_{t}(x)=\left(4.35859-0.08982 S_{t}\right) x_{t}-0.80893^{*} 10^{-4} x_{t}^{2} .
$$

The natural growth rate increased, to the maximum rate, with increasing stock size. After reaching the maximum rate, increasing stock resulted in lower growth rate (Figure 1). The natural growth rate during the El Niño was greater than that during La Niña episode, as indicated by sustained positive values of the southern oscillation index.

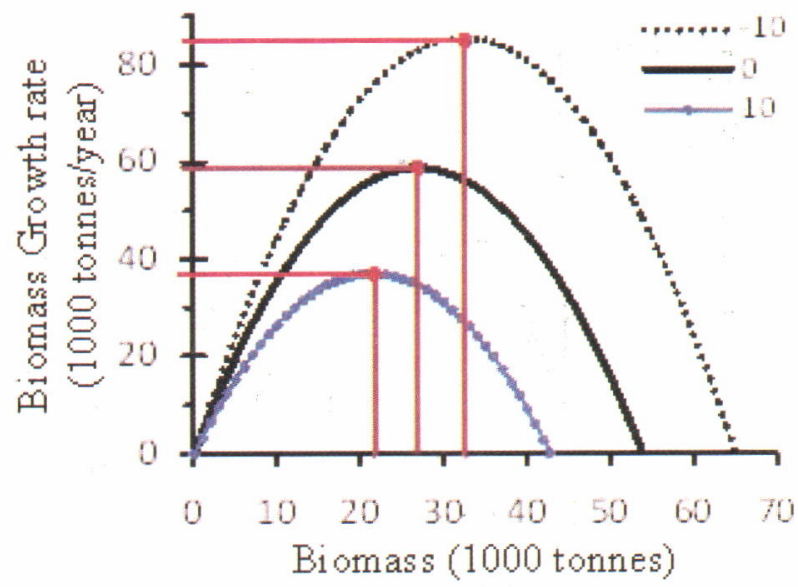

Figure 1.

The relationship between the growth and biomass of the sardine stocks in the Bali Strait at different southern oscillation index, namely $-10,0$, and 10.

The development of fishing effort in the Bali Strait small pelagic fishery decreased the sardine biomass. The sardine biomass also decreased with increasing southern oscillation index. The following equation represented a relationship between the sardine biomass and fishing effort and southern oscillation index:

$$
x_{t}=\left(53,881-1,110.4 S_{t}\right)-160.096 E_{t}
$$

In early development of the fishery, increasing fishing effort decreased the sardine biomass (Eqn. 14). Similarly, the sardine biomass decreased with increasing southern oscillation index (Eqn. 14). Decreasing the sardine biomass, in turn, increased the natural growth rate (Eqn.13 and Figure 1).

Therefore, increasing fishing effort also increased the quantity of catch of sardine $\left(h_{t}\right)$. The relationship between the quantity of catch of sardine and fishing effort in the Bali Strait small pelagic fishery was as follows:

$$
h_{t}=\left(697.795-14.3804 S_{t}\right) E_{t}-2.07335 E_{t}^{2}
$$

The catch increased to the maximum sustainable yield with increasing fishing effort. After attaining the maximum sustainable yield, increasing fishing effort resulted in lower catch (Figure 2). 


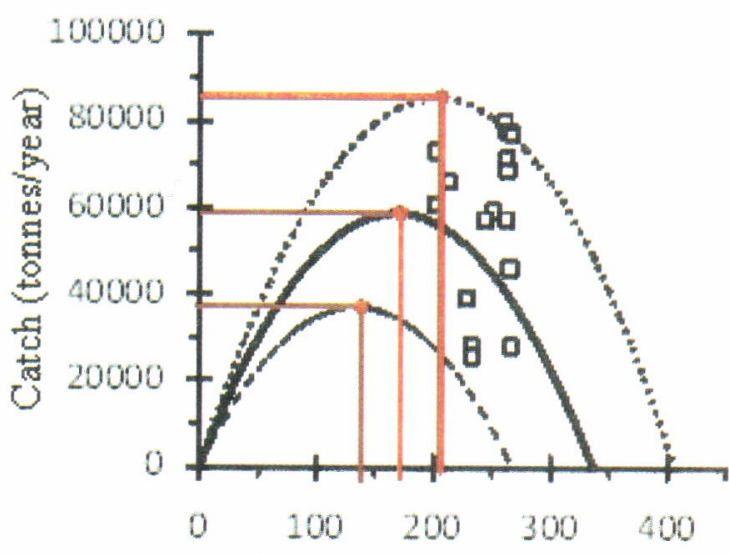

Fishing Effort (Number of boats)

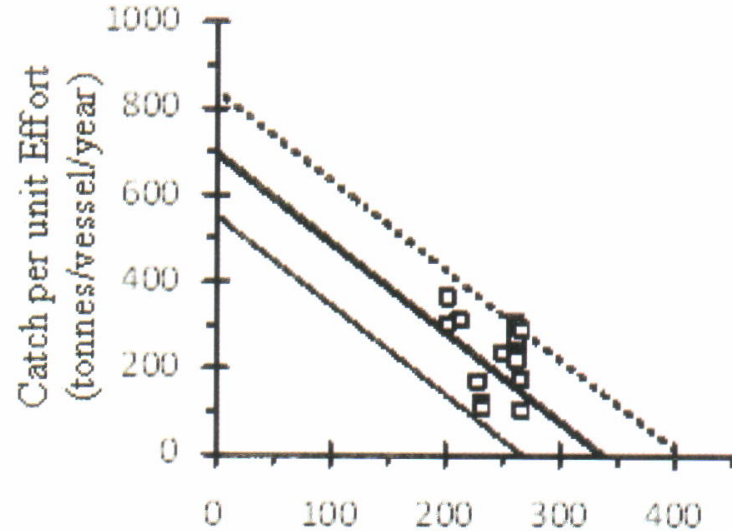

Fishing Effort (number of vessels)
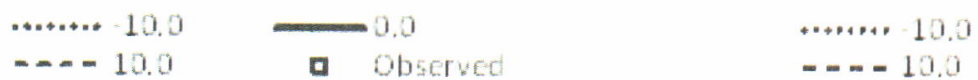

$---19 . j$

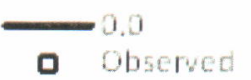

Figure 2. The relationships between (1) the catch of sardine and fishing effort, and (2) catch of sardine per unit effort and fishing effort, in the Bali small pelagic fishery at different southern oscillation index, namely $-10,0$, and 10 .

Meanwhile, the quantity of sardine caught by each vessel, or catch per unit effort $\left(U_{t}\right)$, decreased with increasing fishing effort. The catch of sardine per unit effort in the Bali Strait fishery varied not onily with effort but also with southern osciliation index. Higher effort and higher southern oscillation index resulted in lower $U_{1}$ (Figure 2). The following equation represents a relationship between $U$ and fishing effort:

$$
U_{i}=\left(697.795-14.3804 S_{i}\right)-2.07335 E_{i}
$$

During Ei Nirio episodes, as the natural growth rate and carrying capacity of the sardine biomass increased, the quantity of catch of sardine, and the productivity of fishing vessel targeting the sardine stock, indicated by the catch per unit effort, were greate: (Figure 2). Consequently, the optimal yield and optimal fishing effort were larger during the EI Niño. The maximum sustainable yield and the biologically optimal effort ( $E_{M S Y}$ ), that is the effort required to achieve the maximum sustainable yield, at different climatic conditions could be estimated by the following equations:

$$
\begin{aligned}
& M S Y=3,090.5\left(4.35859-0.08982 S_{t}\right)^{2} \ldots \\
& E_{\text {MSY }}=168.277-3.46792 S_{t} \ldots \ldots \ldots \ldots \ldots \ldots \ldots
\end{aligned}
$$

The result of analysis shows that the level of fishing effort at the maximum sustainable yield also varied with climatic conditions (Figure 2). In EI Niño episodes, the effort required to achieve maximum sustainable yield was greater, vessel productivity was higher, and the maximum sustainable yield resulting was larger. On the contrary, during La Niña episode, the effort required to achieve the maximum sustainable yield should be reduced (Figure 2).

In year 2007, the average southern oscillation index was 1.45. Therefore, the natural growth rate and the carrying capacity of the Bali Strait sardine stock were estimated to be 4.228 and 52,271 tonnes/year, respectively. The level of fishing effort in 2007 was 230 vessels. Meanwhile the biologically optimal level of fishing effort was estimated to be 163 purse seine vessels. Therefore, the fishing effort in 2007 was higher than the biologically optimal level, indicating that the sardine stock in the Bali Strait was biologically over exploited.

The southern oscillation index fluctuated during 1990-2004. Therefore, the estimated catch and the estimated catch per unit effort in the Bali strait sardine fishery were fluctuated (Figure 3 ). The estimates of the $E_{\text {MSY }}$, the maximum sustainable yield and the catch per unit of effort associated with maximum sustainable yield were also fluctuated (Figure 3). As the Bali sardine fishery was more productive in El Niño episodes, the catch per unit of effort and the catch in El Niño episodes were higher than those in La Niña episode. 

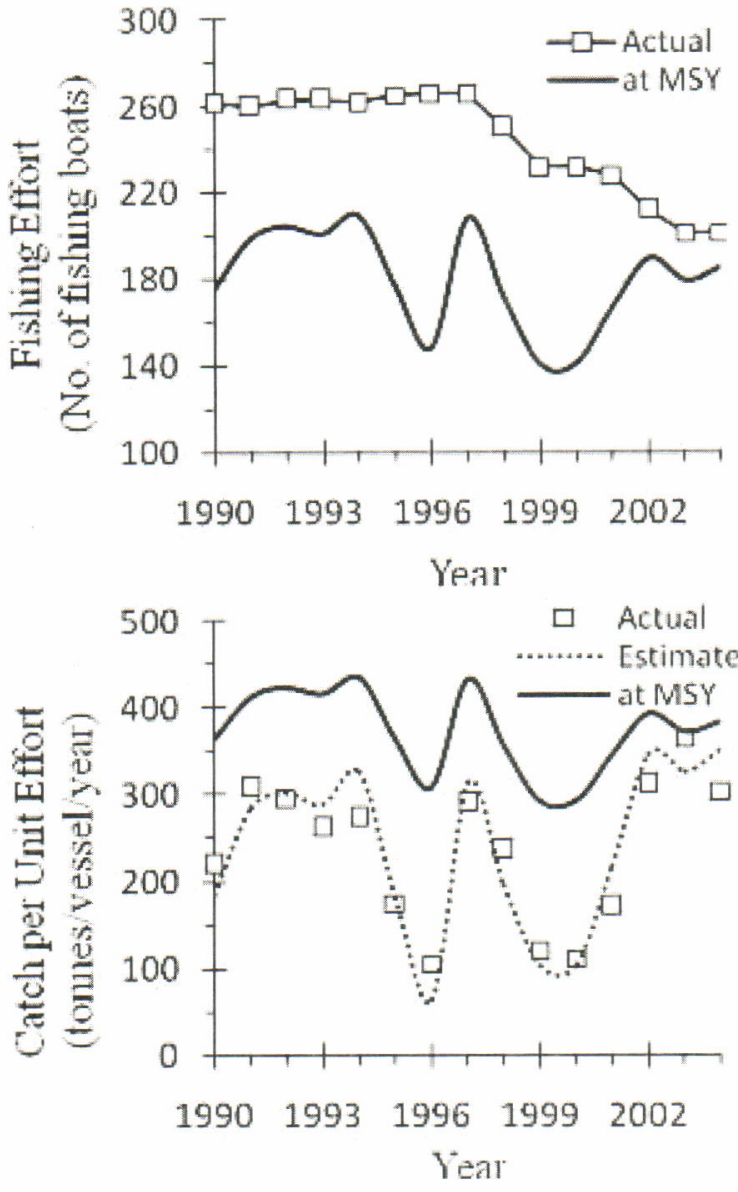
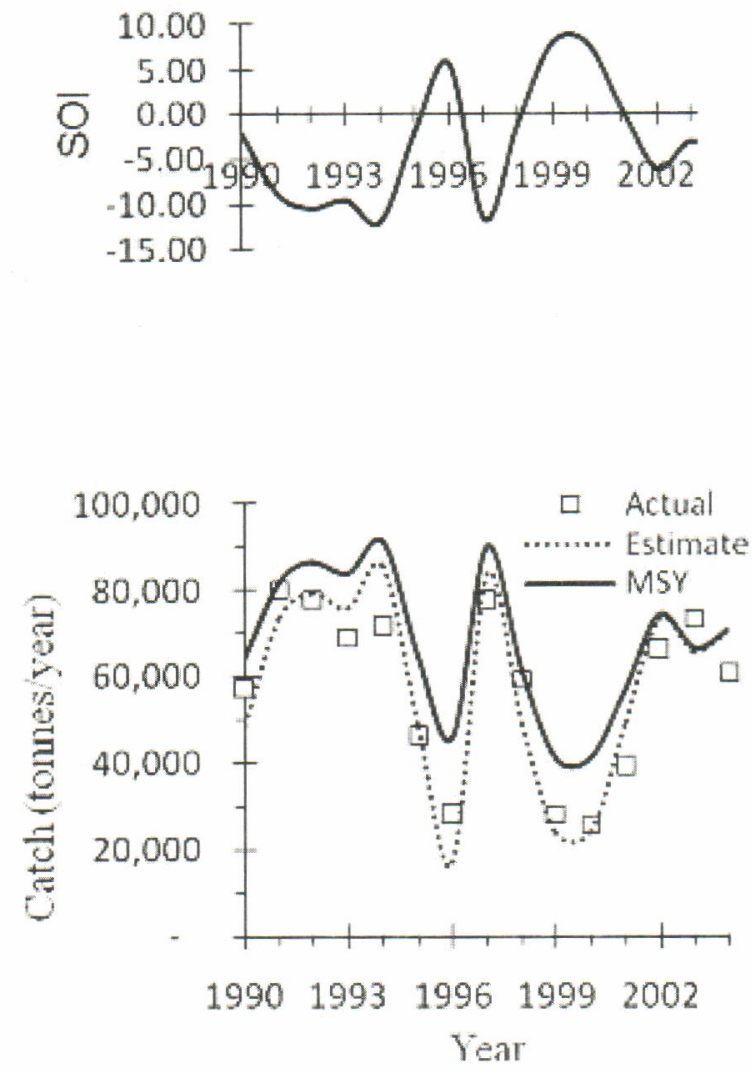

Figure 3. The development of fishing effort, and the fluctuation of southern oscillation index, the catch per unit effort and the catch of sardine in the Bali Strait small pelagic fishery, 1990-2004.

The actual fishing effort in the Bali Strait sardine fishery tended to be level off during 1990-1997, then declined gradually afterward. The actual fishing effort was higher than the $\mathrm{E}_{\mathrm{MSY}}$ during 1990-2004 (Figure 3). Therefore, it could be concluded that the Bali Strait sardine biomass was over exploited. The consequences of the over exploitation were the yield and the catch per unit of effort were lower than the maximum sustainable yield and the catch per unit of effort at maximum sustainable yield, respectively (Figure 3).

\section{Economic of Fishery and Resource Rent}

In 2005, the average price of the catch and the cost of fishing were about Rp.2100/kilogram and about Rp.394 million/vessel/year, respectively. Therefore, the value of fish production from the Bali Strait sardine stock $(\operatorname{TR}(x))$ and the cost of fishing $(\operatorname{TC}(x))$ at different level of biomass and southern oscillation index could be estimated by using the following equations:

$\operatorname{TR}(x)=2.1\left[\left(4.35859-0.08982 S_{t}\right) x_{t}-0.80893^{\star} 10^{-4} x_{t}^{2}\right] .(19$
$\operatorname{TC}(x)=30,387.1\left(4.35859-0.08982 S_{t}-0.80893^{\star} 10^{-4} x_{t}\right)(20$

Figure 4, that was derived from equations (18) and (19), shows that the value of sardine production increases with increasing biomass up to a maximum level, then decreases with further increases in biomass. The total value of production from sardine biomass in the Bali Strait also varies with climatic variation. The sardine biomass produced higher revenue during the $\mathrm{EI}$ Niño. Meanwhile, the cost of fishing decreases with increasing biomass (Figure 4). Therefore, the same revenue from the Bali Strait fishery may be produced with the lower fishing cost, generating higher resource rent, at the higher biomass (Figure 5).

The relationship between the resource rent (RR (x)) and the biomass of sardine at different climatic conditions was represented by the following equation:

$R R(x)=\left[2.1-30,387.1 / x_{t}\right]\left[\left(4.35859-0.08982 S_{t}\right) x_{t}-\right.$

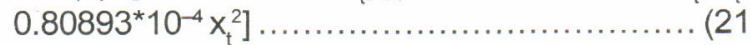


Resource rent is negative at very low biomass (Figure 5). The rent increases with increasing biomass up to a maximum level, then decreases with further increases in biomass. The rent generated in the Bali
Strait sardine fishery also varies with climatic variation. The sardine biomass produced higher resource rent during the El Niño.

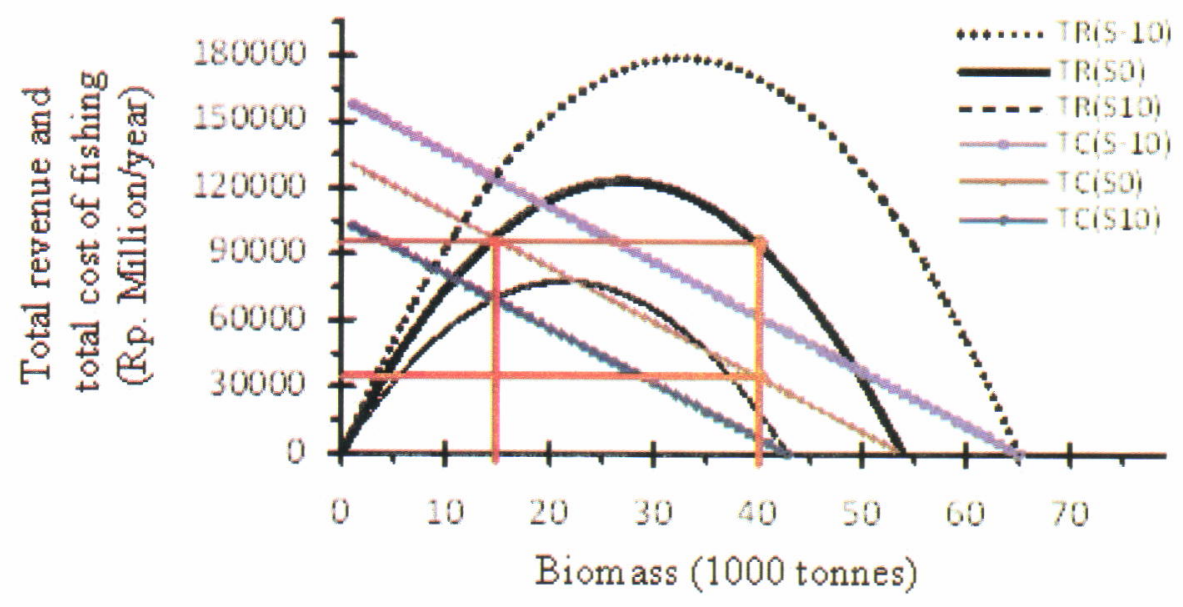

Figure 4. The relationships between the value of sardine production, and the cost of fishing, and sardine biomass in the Bali Strait at different southern oscillation index. [TR (S10) and TC (S10) are total revenue and total cost of fishing when the southern oscillation index is 10].

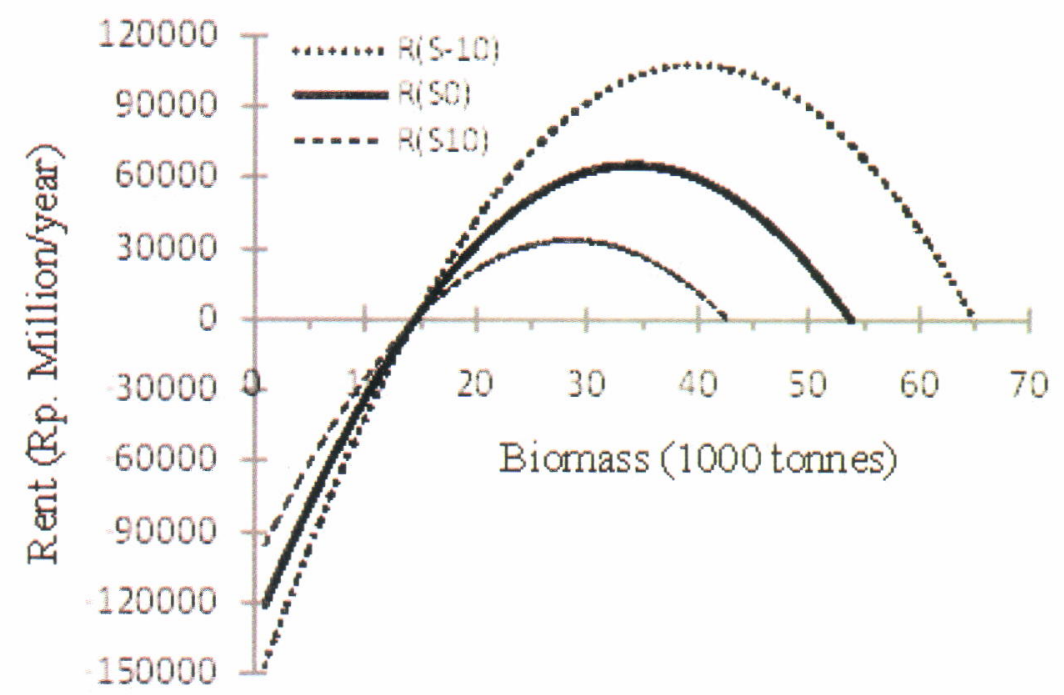

Figure 5. The relationships between resource rent and sardine biomass in the Bali Strait at different southern oscillation index. [R (S10) is resource rent gained at southern oscillation index of 10]. 
The effort required to achieve the optimal resource rent $\left(E_{M E Y}\right)$ and the economically optimal production maximum economic yield at different climatic conditions can be estimated by the following equations:

$$
E_{M E Y}=\left(168.277-3.46792 S_{t}\right)-45.1917
$$

$$
\text { MEY }=3,090.5\left(4.35859-0.08982 S_{t}\right)^{2}-4,234.38 \cdot(23
$$

The estimates of the economically optimal fishing effort $\left(E_{M E Y}\right)$ in 1990-2004 are presented in Figure 6. This figure shows that the actual effort during 19902004 exceeded the economically optimal effort. Consequently, the rents were not optimum (Figure 7). The impact of climatic condition and the over exploitation of sardine stock in the Bali Strait during La Niña episode in 1996 and 1999-2000 have resulted in negative resource rent.

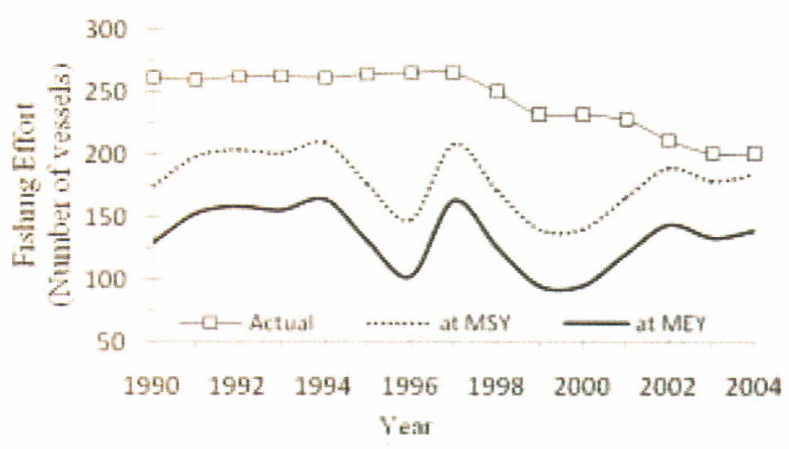

Figure 6. Fluctuation of fishing effort in the Bali Strait small pelagic fishery and the optimal levels of fishing effort (effort at maximum sustainable yield and at maximum economic yield) for sardine, 1990-2004.

In the last century (1908-2007), the average southern oscillation index was about -0.02 . The optimal levels of fishing effort, biomass, harvest, catch per unit effort, total revenue, total cost, and rent generated in the Bali Strait sardine fishery estimated on the basis of this environmental condition are presented in Table 1. The estimated optimal resource rent that could be generated from the utilisation of

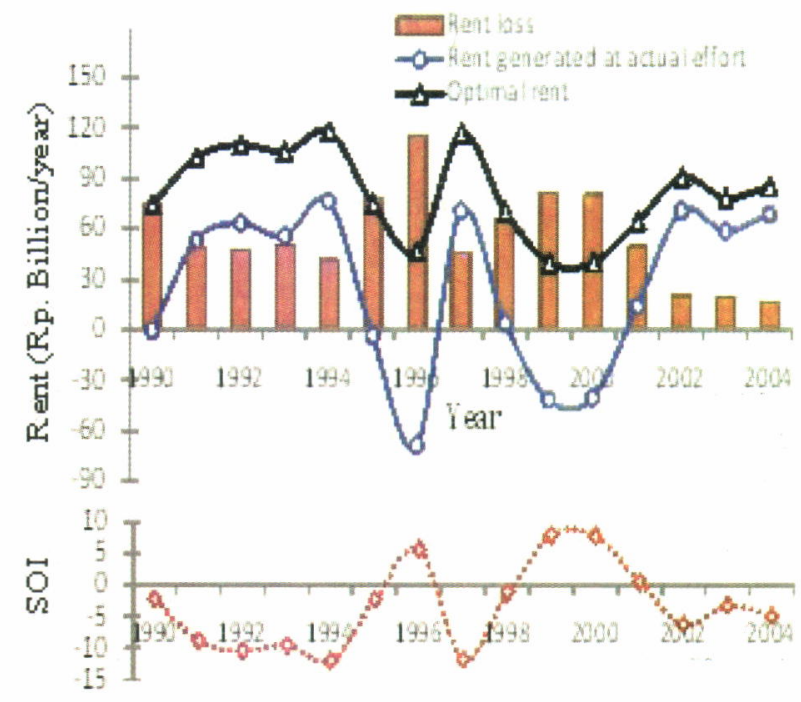

Figure 7. Fluctuation of resource rent and rent loss in the Bali Strait sardine fishery and southern oscillation index 19902004.

the sardine stock in the Bali Strait under the environmental condition of the last century, indicated by that average southern oscillation index, was about Rp.66 billion per year by operating 123 purse seine vessels (Table 1). Meanwhile, the number of purse seine vessels targeting sardine stock in that fishing area was 230 units in 2007 . The estimated resource rent generated in that fishery was about $\mathrm{Rp} .16$ billion in 2007. Therefore, the fishing effort in 2007 was higher than the economically optimal level, indicating that the sardine stock in the Bali Strait was economically over exploited. The resource rent loss in 2007 was about $75 \%$ of the potential rent.

If the fishing effort was at the level that biologically optimum, resulting in the maximum sustainable yield, total revenue was estimated to be at the maximum level (Table 1). However, the resource rent was lower than the potential rent. At the biologically optimal fishing effort, the resource rent loss was about $13 \%$ of the potential rent. 
Table 1. Fishing effort, biomass, harvest, catch per unit of effort, total revenue, total cost, and rent generated in the Bali Strait sardine fishery in 2007 and their estimated economically optimal levels

\begin{tabular}{|c|c|c|c|c|c|c|}
\hline & \multirow[t]{2}{*}{ Units } & \multirow{2}{*}{$\begin{array}{l}\text { Year } \\
2007\end{array}$} & \multirow{2}{*}{$\begin{array}{c}\text { Biologically } \\
\text { optimum }\end{array}$} & \multirow{2}{*}{$\begin{array}{c}\text { Economically } \\
\text { optimum }\end{array}$} & \multicolumn{2}{|c|}{$\begin{array}{l}\text { Difference from } \\
\text { economically } \\
\text { optimum }\end{array}$} \\
\hline & & & & & $\begin{array}{l}\text { Year } \\
2007\end{array}$ & $\begin{array}{c}\text { Biologically } \\
\text { optimum }\end{array}$ \\
\hline $\begin{array}{l}\text { Fishing effort } \\
\text { Biomass } \\
\text { Harvest } \\
\text { Catch per unit of effort } \\
\text { Total revenue } \\
\text { Total cost } \\
\text { Rent } \\
\end{array}$ & $\begin{array}{l}\text { Vessels } \\
\text { tonnes } \\
\text { Tonnes/year } \\
\text { tonnes/vessel } \\
\text { Rp. } 10^{\circ} \text { /year } \\
\text { Rp. } 10^{\circ} \text { year } \\
\text { Rp. } 10^{\circ} \text { /year }\end{array}$ & $\begin{array}{c}230 \\
17.081 \\
50.879 \\
221 \\
106.845 \\
90.513 \\
16.333 \\
\end{array}$ & $\begin{array}{c}168 \\
26.952 \\
58.760 \\
349 \\
123.396 \\
66.250 \\
57.146 \\
\end{array}$ & $\begin{array}{c}123 \\
34.187 \\
54.525 \\
443 \\
114.503 \\
48.465 \\
66.038 \\
\end{array}$ & $\begin{array}{c}-107 \\
17.106 \\
3.647 \\
222 \\
7.658 \\
-42.047 \\
49.705 \\
\end{array}$ & $\begin{array}{c}-45 \\
7.235 \\
-4.234 \\
94 \\
-8.892 \\
-17.784 \\
8.892 \\
\end{array}$ \\
\hline
\end{tabular}

\section{Discussion}

The result of analysis showed significant effects on the catch per unit of effort in Bali sardine fishery of changes in the number of vessels and the climatic variation, as indicated by the fluctuation in southern oscillation index. This, in turn, affects fishers' income and resource rent. The income and resource rent generated in the Bali Strait sardine fishery also vary with climatic variation.

Management of the Bali sardine fishery is required to ensure sustainability of the fisheries and to optimise economic benefits from utilization of the resources. The sardine fishery in the Bali Strait is jointly managed by the Provincial Governments of East Java and Bali. The earliest initiative to manage fishery in the Bali Strait took place in 1977 when the small pelagic fish stocks in this area was over exploitated as a result of the development of the fishing capacity of purse seine fleet beyond the capacity of fish stocks to sustain. Management measures to deal with the over exploitation have been agreed by their stakeholders, consisting of provincial and district government, law enforcement institutions, fishers, and fish processors. The measures include the implementation of a maximum allocation of fishing vessels for fishers from the Provinces of East Java and Bali.

Those two Provinces had agreed in 1977 to only allowed 100 vessels to fish in the Bali Strait. This agreement, however, was not complied as the number of purse seiners continuously increased, the number of fishing boats operated in the Bali Strait were more than the number of boats allowed (Figure 8). Then, those two provinces changed this allocation to 133 vessels in 1978, and further changed to 273 vessels in 1985 . The situation was completely reversed in
1986 and after, for which the number of boats in operation was always less than the number of licences granted. The allocation agreed in 1985 was reviewed in 1992, but no change was made in the number of vessels allowed to fish.

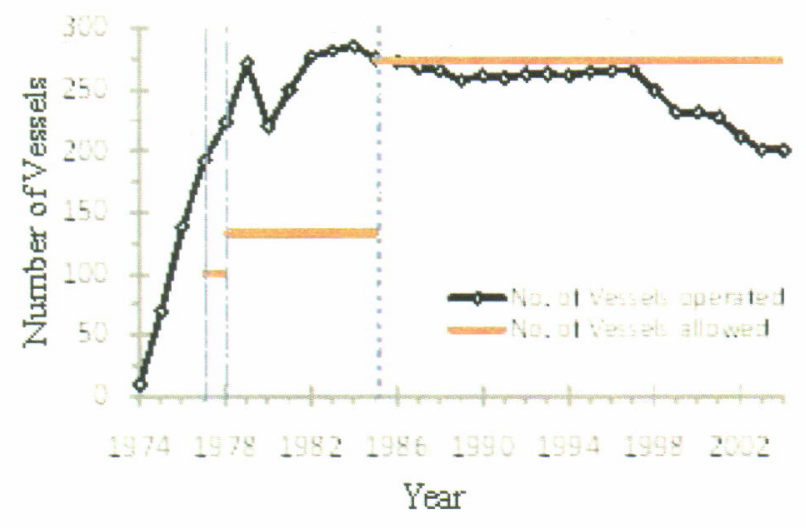

Figure 8. The number of vessels allowed to fish and the number of purse seiners operated in the Bali Strait, 19742004.

The results of the analyses are clearly show that the total allowable fishing effort for the Bali Strait pelagic fishery targeting sardine stock agreed by both the Provincial Governments in year 1986, amounting of 273 vessels, however, was higher than the optimal level required to catch at the maximum sustainable yield level. As the optimal fishing effort needed to generate the optimal rent is lower than the effort asociated with maximum sustainable yield, therefore the total allowable fishing effort was also higher than the optimal fishing effort needed to generate the optimal rent. 
Meanwhile, the actual fishing effort for the Bali Strait pelagic fishery targeting sardine, even though lower than the total allowable fishing effort, was higher than the optimal level required to generate the optimal rent. Therefore, the Bali sardine stock was biologically and economically over exploited during 1990-2004. To optimise resource rent, the fishing effort targeting sardine stock in the Bali Strait should be decreased.

\section{CONCLUSIONS}

1. The results of the analyses presented previously clearly show that the level of fishing effort required to achieve maximum sustainable yield $\left(E_{M S Y}\right)$ and the level of fishing effort required to generate resource rent $\left(E_{M E Y}\right)$ fluctuate with climatic variation.

2. Meanwhile, the total allowable fishing effort for the Bali Strait pelagic fishery targeting sardine stock total allowable fishing effort agreed by both the Provincial Governments in year 1986 is a single value and higher than the $E_{M S Y}$ and the $E_{M E Y}$. The implementation of total allowable fishing effort led to the over exploitation of the Bali sardine stock. The over exploitation causes a rent loss.

3. To optimise resource rent, the fishing effort targeting sardine stock in the Bali Strait should be decreased. The optimal resource rent generated in the Bali Strait sardine fishery fluctuates with climatic variation. As the $\mathrm{E}_{\mathrm{MEY}}$ varies with climatic and economic conditions, the total allowable fishing effort should be adjusted periodically on the basis of the climatic and economic conditions in order to achieve the economically optimal level of resource rent.

\section{REFERENCES}

Anonymous. 1999. Report of a Workshop on the Fishery and the Management of Bali Sardinella (Sardinella Lemuru) in Bali Strait, Denpasar, Bali, Indonesia. 6-8 April 1999. Food and Agriculture Organization. Rome.

Australian Bureau of Meteorology. 2008. Southern Oscillation Index Archives 1876 to Present. (http:/ /www.bom.gov.au).

Clark, C. W. 1976. Mathematical Bioeconomics: The Optimal Management of Renewable Resources. John Wiley and Sons. New York.
Cadima, E. L. 2003. Fish stock assessment manual. Food and Agriculture Organization Fisheries Technical Paper. No.393. Rome. Food and Agriculture Organization. $161 \mathrm{pp}$.

Freon, P. 1986. introduction of environmental variables into global production models. Int. Symp. Long Term Changes Mar. Fish Pop. Vigo.

Ghofar, A., C. P. Mathews, I G. S. Merta, \& S. Salim. 2000. Incorporating the southern oscillation indices to the management model of the Bali Strait sardinella fishery. Papers Presented at the Workshop on the Fishery and the Management of Bali Sardinella (Sardinella lemuru) in Bali Strait, Denpasar, Bali, Indonesia. 6-8 April 1999. Food and Agriculture Organization. Rome.

Merta, I G. S. 1992. Dinamika populasi ikan lemuru, Sardinella lemuru Bleeker 1853 (Pisces: Clupeidae) di perairan Selat Bali dan alternatif pengelolaannya [Population dynamics of Sardinella lemuru Bleeker 1853 (Pisces: Clupeidae) in the Bali Strait and its management alternatives]. Disertasi. Program Pascasarjana. Institut Pertanian Bogor. Bogor.

Merta, I G. S. \& H. M. Eidman. 1995. Prediction of biomass, yield, and value of the lemuru (Sardinella lemuru) fishery in the Bali Strait. in Potier, M. \& S. Nurhakim (eds.). BIODYNEX, a report of the seminar on Biology, Dynamic, and Exploitation of the Javanese purse seiners fisheries, held in Jakarta, Indonesia in March 1994. The Java Sea Pelagic Fishery Assessment Project. Jakarta. 137144.

Merta, I G. S., K. Widana, Yunizal, \& R. Basuki. 2000. Status of the lemuru fishery in Bali Strait its development and prospects. Papers Presented at Workshop on the Fishery and the Management of Bali Sardinella (Sardinella lemuru) in Bali Strait, Denpasar, Bali, Indonesia. 6-8 April 1999. Food and Agriculture Organization. Rome.

Yosidawati, M.. 2004. A management alternative for Bali sardine fishery. Thesis. Diponegoro University. Semarang.

Purwanto. 1992. Rente ekonomi dan tingkat pengusahaan sumber daya perikanan lemuru di perairan Selat Bali (Economic rent and optimal utilisation of Indian oil sardine fishery resources in the Bali Strait). Jurnal Ekonomi Lingkungan. 1 (3): 28-39. 
Ritterbush, S. W. 1975. An Assessment of the Population Biology of the Bali Strait Lemuru Fishery. LPPL 1/75-PL. 051/75. 37 pp.

Schaefer, M. B. 1957. Some considerations of population dynamics and economics in relation to the management of marine fisheries. Journal of the Fisheries Research Board of Canada. 14: 66981.

Schnute, J. 1977. Improved estimates from the Schaefer production model: theoretical considerations. Journal of the Fisheries Research Board of Canada. 34: 583-603.
Sujastani, T. \& S. Nurhakim. 1982. Potensi sumber daya perikanan lemuru (Sardinella longiceps) di Selat Bali. Prosiding Seminar Perikanan Lemuru. Banyuwangi. Tanggal 18-21 Januari 1982. Pusat Penelitian dan Pengembangan Perikanan. Departemen Pertanian. Jakarta. 1-11.

Salim, S. 1986. Assessment of the lemuru (Sardinelia longiceps) fishery in the Bali Strait, Indonesia. Dissertation. School of Anim. Biol. Univ. Coll. North Wales. Bangor. U. K. 


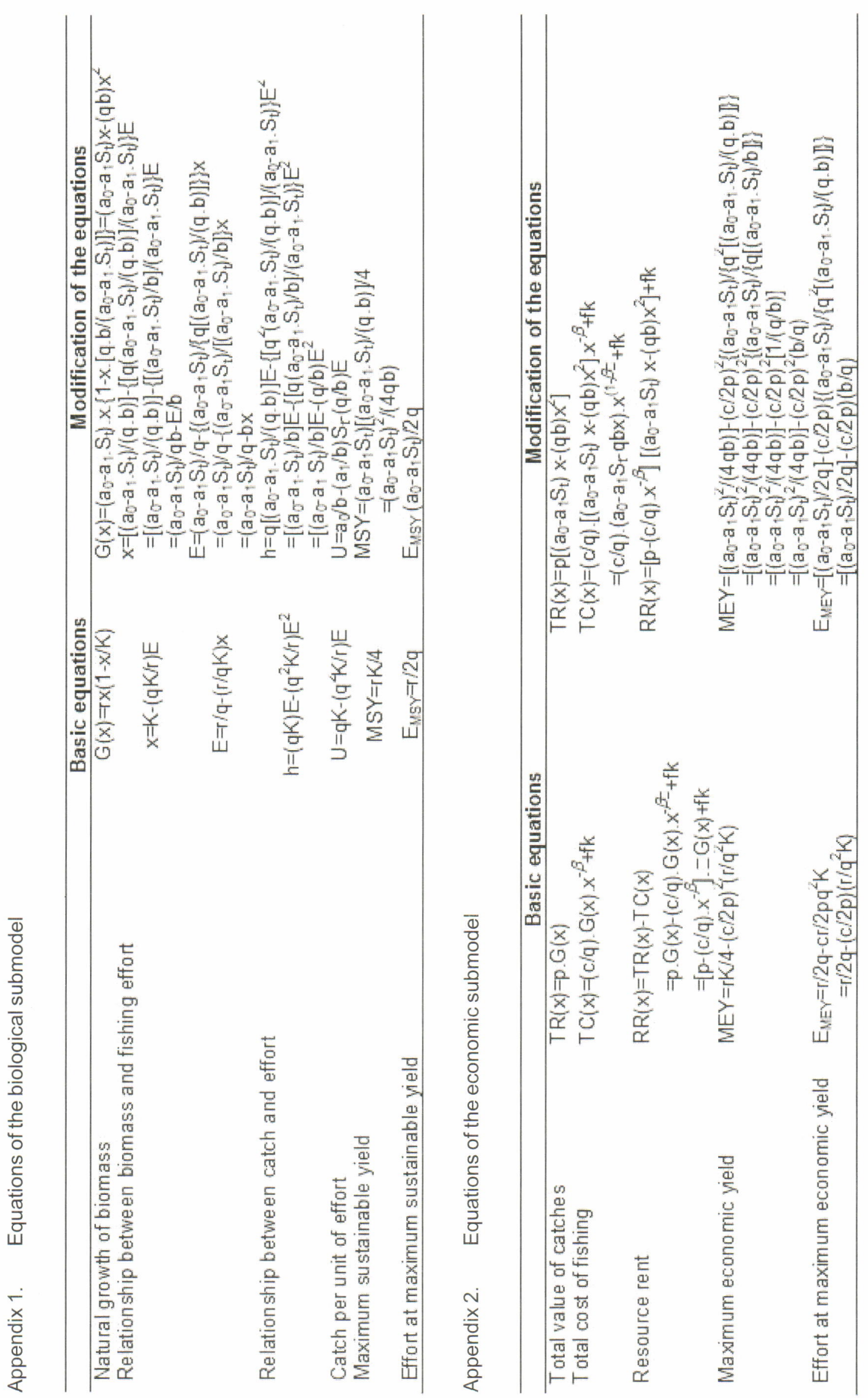


Appendix 3. Catch, effort, and southern oscillation index, 1990-2004

\begin{tabular}{|c|c|c|c|c|}
\hline Year & Catch $^{\text {") (tonnes) }}$ & Effort $^{1 /}$ (vessels) & Catch per vessel (tonnes) & Southern oscillation index ${ }^{2)}$ \\
\hline 1990 & 57,457 & 262 & 219 & -2.19 \\
\hline 1991 & 80,169 & 260 & 308 & -8.78 \\
\hline 1992 & 77,872 & 263 & 296 & -10.38 \\
\hline 1993 & 68,945 & 263 & 262 & -9.47 \\
\hline 1994 & 71,605 & 262 & 273 & -11.93 \\
\hline 1995 & 46,089 & 265 & 174 & -2.27 \\
\hline 1996 & 27,986 & 266 & 105 & 5.69 \\
\hline 1997 & 77,310 & 266 & 291 & -11.67 \\
\hline 1998 & 59,312 & 250 & 237 & -1.08 \\
\hline 1999 & 28,068 & 232 & 121 & 7.95 \\
\hline 2000 & 25,705 & 232 & 111 & 7.80 \\
\hline 2001 & 39,132 & 228 & 172 & 0.53 \\
\hline 2002 & 66,082 & 212 & 312 & -6.10 \\
\hline 2003 & 73,257 & 201 & 364 & -3.14 \\
\hline 2004 & 61,023 & 201 & 304 & -4.82 \\
\hline
\end{tabular}

Appendix 4. Investment and operating costs, 2005

a. Investment costs

\begin{tabular}{lccc} 
& Price (Rp.10 $0^{6}$ unit) & Number (units) & Investment cost $\left(\right.$ Rp. $\left.\mathbf{1 0}^{\mathbf{6}}\right)$ \\
\hline Hull & 244.6 & 2 & 489.2 \\
Engine & 173.7 & 3 & 521.1 \\
Fishing gear & 180.1 & 1 & 180.1 \\
Others & 20.1 & 1 & 20.4 \\
\hline Total & & & $\mathbf{1 , 2 1 0 . 8}$ \\
\hline
\end{tabular}

b. Operating costs

\begin{tabular}{cc}
\hline & Amount (Rp.10 $\mathbf{0}^{\mathbf{y}}$ year) \\
\hline Logistic cost & 147,052 \\
Fuel & 56,764 \\
Lubricant & 7,657 \\
Ice & 34,935 \\
Food & 14,221 \\
Other & 17,634 \\
Fuel subsidy & 15,841 \\
Labour cost & 144,000 \\
Fixed cost & 102,481 \\
Repair and maintenance & 41,600 \\
Fishing fee & 336 \\
Interest on asset & 60,545 \\
\hline
\end{tabular}

